\title{
THE FLEXION REFLEX AS A DIAGNOSTIC TOOL
}

\author{
By G. M. Pool, M.D. \\ Zuiderziekenhuis, Rotterdam, Holland
}

\begin{abstract}
Illustrated by two different cases the importance of the flexion reflex as a diagnostic tool is discussed. It is emphasised that the flexion reflex has more qualities than withdrawal in defence only. In the patient with a long-standing paraplegia a disturbance of the balance between flexion reflex and stretch reflex is of clinical importance.
\end{abstract}

Key words: Flexion reflex; Warning reflex.

\section{Introduction}

REFLEX movements in legs of patients with a spinal cord lesion have drawn much attention of research workers in the last century. In I860 Brondgeest already reported on reflex movements of frogs with a cervical transection of the cord in connection with the problem of muscle tone. Sherrington repeated the experiments of Brondgeest on cats and confirmed them according to Granit (I966), and he also introduced the term flexion reflex.

Babinski reported in 1898 that in certain pathological conditions the flexion of the toes upon the metatarsus, which is the initial movement in the normal plantar reflex, is replaced by extension of the toes upon the metatarsus in human beings. This was confirmed by Collier in I899, and from that time the reflex of Babinski was introduced worldwide.

Kugelberg et al. (1960) recognised the Babinski sign as the result of encroachment of the receptive field of the normal flexion reflex on that of the normal extension reflex and also that disorders of suprasegmental control impair the discriminating capacity of the reflex mechanism as regards to strength, modality and site of the sensory stimulus.

On the basis of the functional organisation of the spinal cord there are two reflex patterns according to Harpuder (I962):

I. The stretch reflex, subserving posture, and maintenance of posture in locomotion.

2. The general flexion reflex, subserving withdrawal and protection against injury.

\section{The Flexion Reflex}

The flexion reflex is, in patients with a spinal cord lesion, more difficult to interpret than the Babinski sign because of the wide range of possibilities and the extensive receptive field from where the reflex can be elicited.

In pathological conditions it is mostly not clear by what stimulus the legs of the paraplegic patient are withdrawn in flexion. It is well known that a pressure sore, an ingrown toenail and other ailments of the legs can change the so-called spastic condition of the paraplegic patient. The patient with a long-standing 
paraplegia is usually able to recognise changes in the balance of his reflexes, although he cannot specify his symptoms.

Apart from pathological conditions of the legs, intra-abdominal processes can also change the balance between stretch reflex and flexion reflex in paraplegic patients. It is the changing of the balance between flexion actions and stretch resistance that is often noticed by the paraplegic patient himself.

Dolfuss et al. (1974) reported five cases of appendicitis and described a considerable diminishing of spasticity in two of them in the supine position but worsening in the sitting position, he did not describe whether the flexion reflex was more easily provoked with his patients. He mentioned that the unilateral change of spasticity can be a useful sign and that the diagnosis can be difficult in a normal subject and even more in a patient where the main preoccupation, for the practitioner, is that of a urinary complication.

Wanebo et al. (1960) reported from a period of I8 years I2 patients with an appendicitis.

\section{Case I}

\section{Case Reports}

S. M., age 33, sustained a complete spinal cord lesion below T8 after a fall from the second floor. She became totally independent and catheter free although with a slow voiding action. She had a normal i.v.p. and no reflux was found on the cystogram. Four months after her dismissal she reported that she felt sick, and complained especially of the stiffness of her right leg when sitting in her wheelchair and flexion movements hindered her when she changed position. On examination it was obvious that flexion movements were much easier to provoke and much more frequent in the right leg compared with the left one. Besides the flexion movements it seemed as if the right lower quadrant of her abdomen gave more resistance to the examining hand than the left side.

Apart from these observations she had a subnormal temperature and a sterile urine in which there were many red cells. The i.v.p. showed a dilated right ureter, but no obstruction in it was discovered. X-rays of the appendix and gallbladder were normal. No clear diagnosis was reached, and when her symptoms had subsided she was discharged.

Two months later she came in with the same symptoms but with the difference that the left leg showed irritative flexion movements on the slightest stimulus and that the left side of her abdomen appeared to have increased resistance to the examining hand. The i.v.p. showed a normal right ureter but a dilated left one, again no obstruction was found. The culture of her urine was not sterile this time and we gave her the appropriate medicine, and when her symptoms had disappeared she was discharged again. The probable cause of her symptoms was found on a renewed cystogram afterwards which showed a grade 3 reflux on both sides.

After that discovery we left her on a catheter, and now after 8 years she still has a normal renal function and has not shown her symptoms of flexion reflex alarm again.

\section{Case 2}

Mrs K. sustained a complete lesion below $\mathrm{T}_{5}$ after a car accident, which her husband did not survive. She is a mother of I4 children and because of her duties at home she was left on a catheter. She has managed quite well for years, but had troublesome flexion movements of her right leg and she suggested that the probable cause was an attack on her gallbladder.

We knew from regular i.v.p.s that she had a big gallstone and had informed her of that situation. She was admitted, and indeed the flexion reflex was more easy to elicit on the right side compared with the left. Except from the stone on the X-ray, no abnormality was found in all possible tests for gallbladder pathology. 
Although not quite happy with the situation, we decided not to operate on her and shortly afterwards we discovered a 'trigger point' on her right big toe from where the flexion reflex movements were easily elicited, and the probable cause of her gallbladder attack was situated there in her big toe! She was later operated on for an infected cyst of that toe.

\section{Discussion}

According to Kugelberg et al., the flexion reflex patterns form the adequate movement for withdrawal from a stimulus. In pathological conditions of paraplegic patients, however, the reflex should also be looked upon as a warning reflex, warning that something has changed in the balance between flexion reflex and stretch reflex depending on changing situations and the spinal lesion. In a paraplegic patient the flexion reflex has more qualities than withdrawal in defence only.

\section{RÉSUMÉ}

L'importance du reflexen flexion du membre inférior est discussié pour des cas paraplegiques et illustree en deux cas patholoqiques.

\section{ZUSAMMENFASSUNG}

Die Wichtigkeit der beuge-reflex der unteren Extremität wird discussiert in pathologischen Conditionen bei Paraplegiker und illustratiert mit zwei Fälle.

\section{REFERENCES}

Babinski, J. (I898). Du phénomène des orteils et de sa valeur sémiologique. Semaine médicale, 18, $32 \mathrm{I}-322$.

BRONDGEeST (I866). Disquissitiones de Tonus musculorum. Thesis, Utrecht.

Collier, J. (1899). An investigation upon the plantar reflex, with reference to the significance of its variations under pathological conditions, including an enquiry into the aetiology of acquired pes cavus. Brain, 22, 7I-99.

CollieR, J. (1904). The effects of total transverse lesion of the spinal cord in man. Brain, 27, 38-63.

Dollfus, P., Holderbach, G. L., Husser, J. M. \& Jacob-Chia, D. Must appendicitis be still considered as a rare complication in paraplegia? Paraplegia, II, 306-309.

Granit, R. (I966). Charles Scott Sherrington: An appraisal. Nelson and Sons.

HARPuder, K. (1962). Proceedings of Clinical Spinal Cord Injury, Veterans Administration, p. 32.

KugELbERG, E., EkLund, K. \& GRIMSBY, L. (1960). Brain, 83, 394.

Wanebo, H. J., WebB, E. \& Combs, R. (1965). California Medicine, 103, I93-197. 